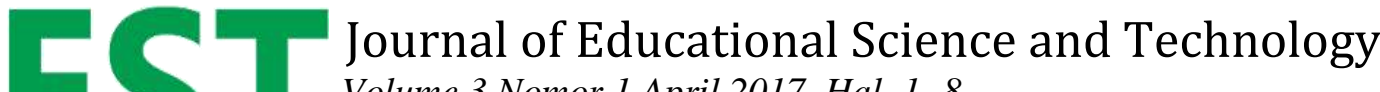 \\ Volume 3 Nomor 1 April 2017 Hal. 1 - 8 \\ p-ISSN: 2460-1497 dan e-ISSN: $2477-3840$
}

\section{Comparison Of The Effectiveness Of Cooperative Learning Model Of Tps Type And Nht Type Based On Independent Learning Students At Makassar}

\author{
Abdul Hadi \\ SMP Negeri 2 Makassar \\ Email: abdulhadi@gmail.com
}

(Received: Desember 2016; Reviewed: Januari 2017; Accepted: Maret 2017; Published: April 2017)

C2017 -EST Program Pascasarjana Universitas Negeri Makassar. Ini adalah artikel dengan akses terbuka dibawah licenci CC BY-NC-4.0 (https://creativecommons.org/licenses/by-nc/4.0/ ).

ABSTRACT

This study aims to: (1) know the effectiveness of cooperative learning model of TPS type; (2) to know the effectiveness of NHT type cooperative learning model; (3) to know the comparison of the effectiveness of cooperative learning model of TPS type with NHT type which viewed from student learning independence. The type of this research is experimental research with pre-test and post-test design. The results of this study indicate that; (1) the application of cooperative type model of TPS is effective on building the flat side space in class VIII4 MTs Negeri 2 Makassar; (2) the application of cooperative NHT type cooperative learning model on the material of flat side room in class VIII MTs Negeri 2 Makassar; (3) there is a difference of effectiveness of cooperative learning model of TPS type with NHT type in terms of student's learning independence on building materials of flat-side classroom VIII MTs Negeri 2 Makassar in high category; (4) there is no difference in the effectiveness of cooperative learning model of TPS type with NHT type in terms of students' self-reliance on building materials on the flat side of class VIII MTs Negeri 2 Makassar in non-high category.

Keywords: Cooperative learning; Independence; learn

\begin{abstract}
ABSTRAK
Penelitian ini bertujuan untuk: (1) mengetahui keefektifan model pembelajaran kooperatif tipe TPS; (2) mengetahui keefektifan model pembelajaran kooperatif tipe NHT; (3) mengetahui perbandingan keefektifan model pembelajaran koperatif tipe TPS dengan tipe NHT yang ditinjau dari kemandirian belajar siswa. Jenis penelitian ini adalah penelitian eksperimen dengan design pre-test dan post-test. Hasil penelitian ini menunjukkan bahwa; (1) penerapan model pembelajaran kooperatif tipe TPS efektif pada materi bangun ruang sisi datar pada kelas VIII 4 MTs Negeri 2 Makassar; (2) penerapan model pembelajaran kooperatif tipe NHT efektif pada materi bangun ruang sisi datar pada kelas VIII MTs Negeri 2 Makassar; (3) terdapat perbedaan keefektifan model pembelajaran kooperatif tipe TPS dengan tipe NHT ditinjau dari kemandirian belajar siswa pada materi bangun ruang sisi datar kelas VIII MTs Negeri 2 Makassar pada kategori tinggi; (4) tidak terdapat perbedaan keefektifan model pembelajaran kooperatif tipe TPS dengan tipe NHT ditinjau dari kemandirian belajar siswa pada materi bangun ruang sisi datar kelas VIII MTs Negeri 2 Makassar pada kategori tidak tinggi.
\end{abstract}

Kata Kunci: Pembelajaran kooperatif; kemandirian; belajar 


\section{PENDAHULUAN}

Pendidikan mempunyai peranan yang sangat penting dalam menciptakan sumber daya manusia (SDM) yang berkualitas. Pendidikan merupakan salah satu program nasional yang senantiasa dikembangkan dan disesuaikan dengan tujuan dan kemajuan ilmu pengetahuan dan teknologi untuk menciptakan manusiamanusia pembangunan yang berkualitas, cerdas, terampil, dan mandiri. Hal ini sejalan dengan tujuan pendidikan nasional yang terdapat dalam UU RI No 20 tahun 2003 menyatakan bahwa: Pendidikan nasional berfungsi mengembangkan kemampuan dan membentuk watak serta peradaban bangsa yang bermanfaat dalam rangka mencerdaskan kehidupan bangsa, bertujuan untuk berkembangnya potensi peserta didik agar menjadi manusia yang beriman dan bertaqwa pada Tuhan Yang Maha Esa, berakhlak mulia, berilmu, cakap, kreatif, mandiri dan menjadi warga Negara yang demokratis dan bertanggung jawab.

Berdasarkan tujuan pendidikan nasional yang telah dikemukakan di atas salah satu tolak ukurnya adalah kemandirian siswa. Kemandirian siswa dalam hal ini sangat penting dimiliki oleh siswa agar dalam bersikap dan melaksanakan tugas tidak tergantung pada orang lain dan bertanggung jawab terhadap apa yang telah dikerjakannya. Untuk meningkatkan kemandirian siswa di sekolah maka siswa dilatih dengan memberi tugas yang harus dikerjakan di sekolah maupun di rumah.

Tugas-tugas yang diberikan guru sedapat mungkin dikerjakan oleh siswa secara mandiri untuk melatih pikiran dalam memanfaatkan sumber belajar yang ada. Panen dalam Rusman (2012: 355) mengemukakan bahwa dengan mandiri tidak berarti siswa-siswa belajar secara individualitas, tetapi situasinya dibina untuk belajar kelompok dan setiap siswa menjadi parner sesamanya.

Kemandirian dalam belajar perlu diberikan kepada peserta didik supaya mempunyai tanggung jawab dalam mengatur dan mendisiplinkan dirinya dalam mengembangkan kemampuan belajar atas kemauannya sendiri. Sikap-sikap tersebut perlu dimiliki peserta didik karena hal tersebut merupaka ciri-ciri kedewasaan orang terpelajar. (Rusman, 2012: 354).

Dalam proses pembelajaran, pengembangan kemampuan berkomunikasi yang baik dengan guru dan sesama siswa yang dilandasi sikap saling menghargai harus perlu dikembangkan di dalam setiap event pembelajaran. Kebiasaan-kebiasaan untuk bersedia mendengar dan menghargai pendapat rekan-rekan sesama siswa sering kali kurang mendapat perhatian oleh guru, karena dianggap sebagai hal rutin yang berlangsung saja pada kegiatan sehari-hari. Padahal kemampuan ini tidak dapat berkembang dengan baik begitu saja, akan tetapi membutuhkan latihan-latihan yang terbimbing dari guru. (Aunurrahman, 2012: 7).

Unsur terpenting dalam proses pembelajaran ialah merangsang serta mengarahkan siswa belajar. Mengajar pada hakikatnya tidak lebih dari sekedar menolong para siswa untuk memperoleh pengetahuan, keterampilan, sikap, serta ide dan apresiasi yang menjurus kepada perubahan tingkah laku dan pertumbuhan siswa (Trianto, 2009: 17). Cara guru mengajar yang baik merupakan kunci dan prasyarat bagi siswa untuk dapat belajar dengan baik. Salah satu tolak ukur bahwa siswa telah belajar dengan baik ialah jika siswa itu dapat mempelajari apa yang seharusnya dipelajari, sehingga indikator hasil belajar yang diinginkan dapat dicapai oleh siswa. Oleh karena itu hendaknya seorang guru menggunakan model pembelajaran yang efektif dan menarik dalam proses penyampaian materi pembelajaran. Salah satu model pembalajaran yang aktif dan interaktif adalah model pembelajaran kooperatif (cooperative learning) karena melibatkan langsung peserta didik dalam kelompokkelompok.

Dalam model pembelajaran kooperatif peserta didik akan berusaha memecahkan suatu masalah bersama dengan teman kelompoknya, bila belum mendapatkan solusinya, baru bertanya kepada guru. Pada model pembelajaran kooperatif peserta didik merupakan subjek pembelajaran. Interaksi sosial yang bersifar positif dapat menciptakan terjadinya kerja sama yang pada akhirnya mempermudah terjadinya asimilasi (pembauran). Interaksi sosial diartikan sebagai pengaruh timbal balik antara dua pihak, antara individu dengan individu atau kelompok lainnya dalam mencapai suatu tujuan. (Idi, 2010: 82).

Model pembelajaran kooperatif tipe TPS dan tipe NHT merupakan salah satu tipe pembelajaran kooperatif yang menekankan pada struktur khusus yang dirancang untuk mempengaruhi pola interaksi siswa dan memiliki tujuan untuk meningkatkan penguasaan akademik. Pada model 
pembelajaran kooperatif tipe TPS dan tipe NHT siswa diberikan kesempatan untuk menyelesaikan sendiri setiap permasalahan yang dihadapinya, tentunya tidak lepas dari pengamatan guru. Namun jika dalam proses bertukar informasi dengan teman kelompoknya belum menemukan solusinya, barulah menanyakannya kepada guru. Sehingga dalam proses belajar mengajar siswa tidak hanya duduk diam untuk menerima dan mencatat saja. Bahkan diantara beberapa siswa bisa menjadi sumber informasi kepada teman-temannya yang lain. Dengan begitu, teman-temannya yang lain bisa saja termotivasi untuk mencari informasi yang berkaitan dengan materi yang akan dipelajarinya.

Berdasarkan uraian tujuan penelitian yang diajukan dalam penelitian ini adalah sebagai berikut: untuk mengetahui (1) pembelajaran matematika efektif dengan penerapan model pembelajaran kooperatif tipe TPS, baik maupun tanpa ditinjau dari kemandirian belajar siswa pada materi bangun ruang sisi datar di kelas VIII $_{4}$ MTs Negeri 2 Makassar, (2) pembelajaran matematika efektif dengan penerapan model pembelajaran kooperatif tipe NHT, baik maupun tanpa ditinjau dari kemandirian belajar siswa pada materi bangun ruang sisi datar di kelas $\mathrm{VIII}_{9}$ MTs Negeri 2 Makassar. dan (3) untuk terdapat perbedaan keefektifan model pembelajaran kooperatif tipe TPS dengan tipe NHT ditinjau dari kemandirian belajar siswa pada materi bangun ruang sisi datar di kelas VIII MTs Negeri 2 Makassar.

Tabel 4.1. Perbandingan indikator keefektifan model pembelajaran kooperatif tipe TPS dan tipe NHT

\begin{tabular}{cccc}
\hline Model & Indikator & Kriteria & Pencapaian \\
pembelajaran & &
\end{tabular}

\begin{tabular}{|c|c|c|c|c|}
\hline & $\begin{array}{ll}\text { 1. Hasil belajar } \\
\text { a. Rata-rata nilai post-test }\end{array}$ & $\bar{x}>70$ & $\bar{x}=72,4$ & Terpenuhi \\
\hline & $\begin{array}{l}\text { b. Nilai gain ternormalisasi } \\
\text { minimal sedang }\end{array}$ & $0,3 \leq \bar{x}_{g}<0,7$ & $\bar{x}_{g}=0,5$ & Terpenuhi \\
\hline & $\begin{array}{l}\text { c. Ketuntasan klasikal } \\
\text { minimal } 75 \%\end{array}$ & $K K \geq 75 \%$ & $K K=79 \%$ & Terpenuhi \\
\hline \multirow[t]{4}{*}{ TPS } & $\begin{array}{l}\text { 2. Aktivitas siswa (AS) } \\
\text { minimal aktif }\end{array}$ & $2,5 \leq A S<3,5$ & $A S=2,8$ & Terpenuhi \\
\hline & & $2,5 \leq R S<3,5$ & $R S=3,4$ & Terpenuhi \\
\hline & 1. Hasil belajar & & & \\
\hline & $\begin{array}{l}\text { a. Rata-rata nilai post-test } \\
\text { melebihi KKM }\end{array}$ & $\bar{x}>70$ & $\bar{x}=71,66$ & Terpenuhi \\
\hline
\end{tabular}




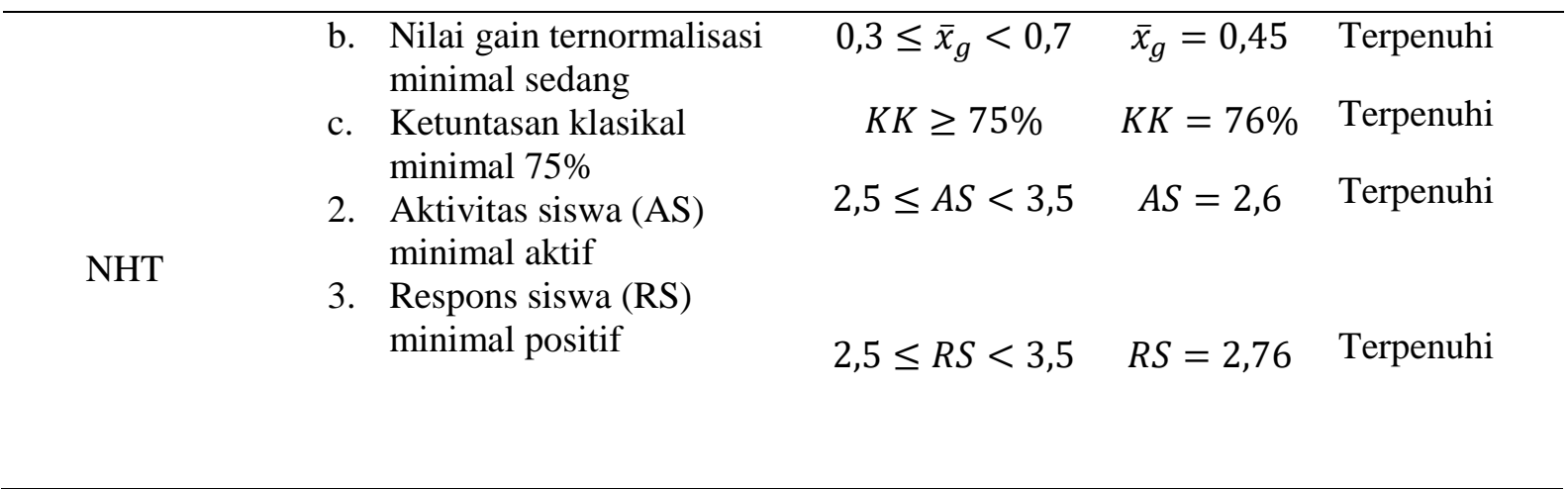

Tabel 4.2. Ketercapaian Kriteria Keefektifan Pembelajaran ditinjau dari kemandirian belajar pada kategori tinggi

\begin{tabular}{|c|c|c|c|c|}
\hline $\begin{array}{l}\text { Model } \\
\text { pembelajaran }\end{array}$ & Indikator & Kriteria & Pencapaian & Keputusan \\
\hline
\end{tabular}

$\begin{array}{ll}\text { TPS } & \text { Respons siswa (RS) } \\ & \text { minimal positif }\end{array}$

1. Hasil belajar
a. Rata-rata nilai posttest melebihi KKM

b. Nilai gain ternormalisasi minimal sedang

c. Ketuntasan klasikal minimal $75 \%$

2. Aktivitas siswa (AS)

$\begin{array}{clc}\bar{x}>70 & \bar{x}=76,8 & \text { Terpenuhi } \\ 0,3 \leq \bar{x}_{g}<0,7 & \bar{x}_{g}=0,6 & \text { Terpenuhi } \\ K K \geq 75 \% & K K & \text { Terpenuhi } \\ 2,5 \leq A S<3,5 & =100 \% & \text { Terpenuhi } \\ 2,5 \leq R S<3,5 & A S=2,8 & \text { Terpenuhi } \\ & R S=3,2 & \end{array}$

Model

Pembelajaran

Indikator

Kriteria

Pencapaian

Keputusan

\begin{tabular}{|c|c|c|c|c|}
\hline NHT & $\begin{array}{ll}\text { 1. } & \text { Hasil belajar } \\
\text { a. } & \text { Rata-rata nilai post- } \\
& \text { test melebihi KKM } \\
\text { b. } & \text { Nilai gain } \\
& \text { ternormalisasi } \\
& \text { minimal sedang } \\
\text { c. } & \text { Ketuntasan klasikal } \\
& \text { minimal 75\% } \\
\text { 2. } & \text { Aktivitas siswa (AS) } \\
\text { 3. } & \text { Respons siswa (RS) } \\
& \text { minimal positif }\end{array}$ & $\begin{array}{c}\bar{x}>70 \\
0,3 \leq \bar{x}_{g}<0,7 \\
K K \geq 75 \% \\
2,5 \leq A S<3,5 \\
2,5 \leq R S<3,5\end{array}$ & $\begin{array}{l}\bar{x}=75 \\
\bar{x}_{g}=0,5 \\
K K \\
=100 \% \\
A S=2,6 \\
R S=3,16\end{array}$ & $\begin{array}{l}\text { Terpenuhi } \\
\text { Terpenuhi } \\
\text { Terpenuhi } \\
\text { Terpenuhi } \\
\text { Terpenuhi }\end{array}$ \\
\hline
\end{tabular}

Tabel 4.3. Ketercapaian Kriteria Keefektifan Pembelajaran ditinjau dari kemandirian belajar pada kategori tidak tinggi

\begin{tabular}{|c|c|c|c|c|}
\hline $\begin{array}{l}\text { Model } \\
\text { pembelajaran }\end{array}$ & Indikator & Kriteria & Pencapaian & Keputusan \\
\hline
\end{tabular}




\begin{tabular}{|c|c|c|c|c|}
\hline TPS & $\begin{array}{ll}\text { 1. } & \text { Hasil belajar } \\
\text { a. } & \text { Rata-rata nilai post- } \\
& \text { test melebihi KKM } \\
\text { b. } & \text { Nilai gain } \\
& \text { ternormalisasi minimal } \\
& \text { sedang } \\
\text { c. } & \text { Ketuntasan klasikal } \\
& \text { minimal 75\% } \\
\text { 2. } & \text { Aktivitas siswa } \\
\text { 3. } & \text { Respons siswa (RS) } \\
& \text { minimal positif }\end{array}$ & $\begin{array}{c}\bar{x}>70 \\
0,3 \leq \bar{x}_{g}<0,7 \\
K K \geq 75 \% \\
2,5 \leq A S<3,5 \\
2,5 \leq R S<3,5\end{array}$ & $\begin{aligned} \bar{x} & =69 \\
\bar{x}_{g} & =0,30 \\
K K & =57 \% \\
R S & =2,6 \\
R S & =2,6\end{aligned}$ & $\begin{array}{l}\text { Tidak } \\
\text { terpenuhi } \\
\text { Terpenuhi } \\
\text { Tidak } \\
\text { terpenuhi } \\
\text { Terpenuhi } \\
\text { Terpenuhi }\end{array}$ \\
\hline NHT & 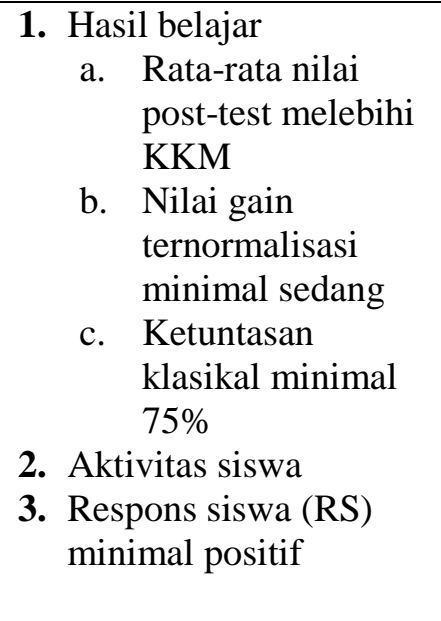 & $\begin{array}{c}K K \geq 75 \% \\
2,5 \leq A S<3,5 \\
2,5 \leq R S<3,5\end{array}$ & $\begin{array}{c}K K=59 \% \\
A S=2,7 \\
R S=3,3\end{array}$ & $\begin{array}{l}\text { Tidak } \\
\text { terpenuhi } \\
\text { Terpenuhi } \\
\text { Terpenuhi }\end{array}$ \\
\hline $\begin{array}{l}\text { Model } \\
\text { pembelajaran }\end{array}$ & Indikator & Kriteria & Pencapaian & Keputusan \\
\hline TPS & $\begin{array}{ll}\text { 1. Hasil belajar } \\
\text { a. Rata-rata nilai post- } \\
\text { test melebihi KKM } \\
\text { b. Nilai gain } \\
\text { ternormalisasi } \\
\text { minimal sedang } \\
\text { c. Ketuntasan klasikal } \\
\text { minimal 75\% } \\
\text { 2. Aktivitas siswa (AS) } \\
\text { 3. Respons siswa (RS) } \\
\text { minimal positif }\end{array}$ & $\begin{array}{c}K K \geq 75 \% \\
2,5 \leq A S<3,5 \\
2,5 \leq R S<3,5\end{array}$ & $\begin{array}{c}K K=77 \% \\
A S=2,9 \\
R S=2,5\end{array}$ & $\begin{array}{l}\text { Terpenuhi } \\
\text { Terpenuhi } \\
\text { Terpenuhi }\end{array}$ \\
\hline \multirow[t]{2}{*}{$\begin{array}{c}\text { Model } \\
\text { Pembelajaran }\end{array}$} & Indikator & Kriteria & Pencapaian & Keputusan \\
\hline & $\begin{array}{ll}\text { 1. Hasil belajar } \\
\text { a. Rata-rata nilai post- } \\
\text { test melebihi KKM } \\
\text { b. Nilai gain } \\
\text { ternormalisasi }\end{array}$ & $\begin{array}{c}\bar{x}>70 \\
0,3 \leq \bar{x}_{g}<0,7\end{array}$ & $\begin{array}{l}\bar{x}=70,3 \\
\bar{x}_{g}=0,43\end{array}$ & $\begin{array}{l}\text { Terpenuhi } \\
\text { Terpenuhi }\end{array}$ \\
\hline
\end{tabular}




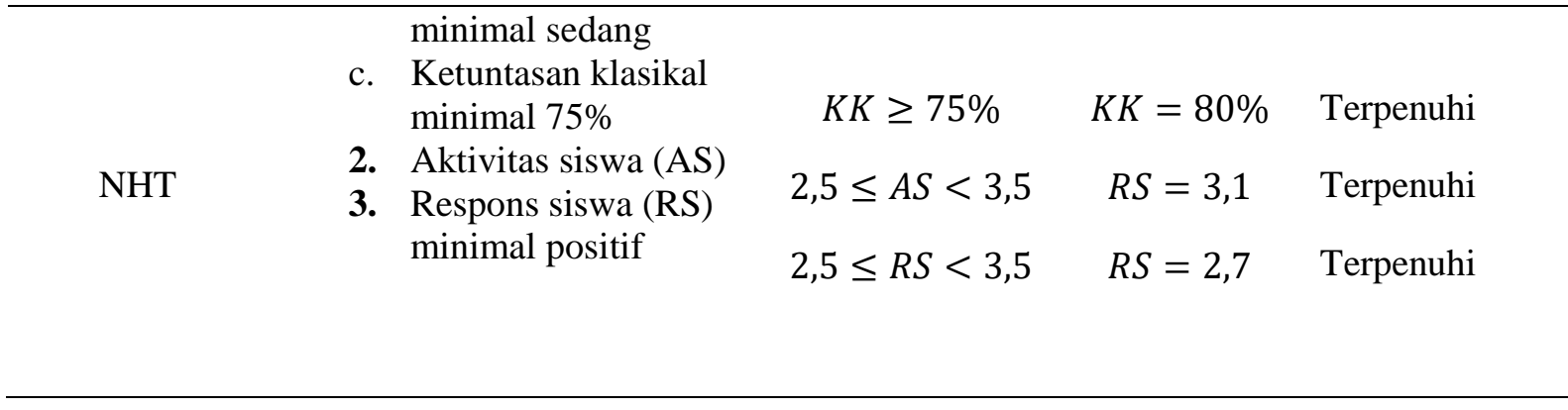

Hasil analisis deskriptif meliputi aktivitas siswa, respons siswa, keterlaksanaan pembelajaran, dan hasil belajar siswa. Sedangkan hasil analisis inferensial meliputi hasil belajar siswa.

\section{Analisis deskriptif}

Berdasarkan hasil analisis aktivitas siswa yang terdapat pada tabel di atas, diperoleh skor rata-rata melebih dari standar yag telah ditetapkan, sehingga indicator keefektifan berdasarkan aktivitas siwa terpenuhi.

Berdasarkan hasil angket respons siswa yng terdapat pada tabel di atas, secara keseluruhan memberi respons siswa positif terhadap pembelajaran. Sehingga indicator keefektifan berdasarkan respons siswa terpenuhi.

Hasil analisis data terlihat bahwa kemampuan siswa dalam pembelajaran matematika yang diperoleh melalui pretest dan tes akhir setelah pembelajaran dengan menggunakan model pembelajaran kooperatif tipe TPS dan model pembelajaran kooperatif tipe NHT pada pembelajaran matematika mengalami peningkatan dari kategori sangat rendah diawal pembelajaran dan berada pada kategori tinggi setelah pembelajaran.

\section{Analisis inferensial}

Efektivitas pembelajaran berdasarkan 3 (tiga) aspek yakni (1) hasil belajar antara siswa yang diajar dengan menerapkan pembelajaran kooperatif tipe TPS lebih baik dari pada siswa yang diajar dengan menerapkan pembelajaran kooperatif tipe NHT, (2) aktivitas siswa yang diajar dengan menerapkan pembelajaran kooperatif tipe TPS lebih baik dari pada siswa yang diajar dengan menerapkan pembelajaran kooperatif tipe NHT, dan (3) respons antara siswa setelah diajar dengan menerapkan pembelajaran kooperatif tipe TPS lebih baik dari pada siswa setelah diajar dengan menerapkan pembelajaran kooperatif tipe NHT. Dengan demikian secara umum penerapan pembelajaran matematika dengan model pembelajaran kooperatif tipe TPS lebih efektif daripada tipe NHT pada materi bangun ruang sisi datar di kelas VIII MTs Negeri 2 Makassar.

\section{SIMPULAN DAN SARAN}

Berdasarkan hasil penelitian dan pembahasan, maka kesimpulan dalam peneleitian ini adalah sebagai berikut: (1) Model pembelajaran kooperatif tipe TPS (Think Pair Share) efektif dalam pembelajaran matematika pada kelas VIII MTs Negeri 2 Makassar. (2) Model pembelajaran kooperatif tipe NHT (Numbered Heads Together) efektif dalam pembelajaran matematika pada kelas VIII MTs Negeri 2 Makassar. (3) Pembelajaran dengan model pembelajaran kooperatif tipe TPS lebih efektif daripada model pembelajaran kooperatif tipe NHT pada siswa kelas VIII MTs Negeri 2 Makassar.

Berdasarkan kesimpulan di atas, maka peneliti menyarankan beberapa hal yang perlu diperhatikan: (1) Bagi guru diharapkan mengimplementasikan pembelajaran matematika dengan model pembelajaran kooperatif tipe TPS dan tipe NHT berdasarkan hasil dan temuan dalam penelitian ini, terutama untuk meningkatkan hasil belajar siswa. (2) Bagi siswa dalam meningkatkan aktivitas terhadap model pembelajaran kooperatif tipe TPS dan tipe NHT, maka disarankan kepada guru untuk lebih memberikan dorongan kepada siswa untuk bekerja sama dalam kelompok dengan mengesampingkan perasaan malu untuk bertanya, saling menghargai dan memperhatikan pendapat dalam kelompoknya. (3) Bagi peneliti berikutnya, perlu melakukan penelitian tentang pembelajaran ini yang menyangkut materi lain dalam matematika dengan mempertimbangkan keterbatasan dalam penelitian ini. 
DAFTAR RUJUKAN

Alma, Buchari. (2008). Guru Profesional.

Bandung: Alfabeta.

Allolayuk, Sertin. (2013) Perbandingan Keefektifan Model Pembelajaran Kooperatif tipe STAD dengan pendekatan Probing Prompting dan Pendekatan Reciprocal Teaching pada Pembelajaran Metematika Siswa Kelas $X$ di SMA Negeri 1 Poso Kota Selatan. Thesis, Tidak Diterbitkan. Makassar: Pascasarjana Universitas Negeri Makassar

Andriasih, Suneti. (2013) Definisi Bangun Ruang. (Online) http://definisibangunruang016.blogspot. com/. Diakses pada tanggal 08 Juli 2014.

Arikunto, Suharsimi. (2010). Dasar-Dasar Evaluasi Pendidikan (Edisi revisi). Jakarta: Bumi Aksara.

Aunurrahaman. (2012). Belajar dan

Pembelajaran. Bandung: Alfabeta.

Azwar, Saifuddin. (2004). Penyusunan Skala Psikologi. Edisi 2. Yogyakarta: Pustaka Pelajar.

Bustam, Irawati. (2013). Komparasi Pembelajaran Kooperatif tipe TAI dan tipe TPS pada Materi Perbandingan Siswa Kelas VII SMP Negeri 9 Palopo. Thesis. Tidak Diterbitkan.Makassar: Pascasarjana Universitas Negeri Makassar.

Depiknas. (2003). Undang-undang RI No 20 Tahun 2003 tentang Sisdikna.

Jakarta: Eko Jaya.

Fhinajeparaz.(2013). Balok dan Unsurunsurnya. (Online). http://fhinajeparaz.wordpress.com/2013/ 01/03/balok-dan-unsur-unsurnya/. Diakses pada tanggal 08 Juli 2014.

Firdaus. (2009). Efektifitas Pembelajaran Kooperatif tipe NHT dalam Pembelajaran Matematika di SMA. Thesis. Tidak Diterbitkan. Makassar. Pascasarjana Universitas Negeri Makassar.

Fitriani, A. (2013). Komparasi Keefektifan Pembelajaran Matematika Melalui Model Kooperatif Tipe Make A Match dan Tipe Scramble Pada Siswa Kelas VII SMP Negeri 4 Palopo. Thesis. Tidak Diterbitkan. Makassar: Pascasarjana Universitas Negeri Makassar.
Ginting, Abdorrakhman. Esensi Praktis Belajar dan Pembelajaran. Bandung: Humaniora.

Haraharp. Negoro. (2013). Ensiklopedia Matematika. Ghalia Indonesia: IKAPI.

Hasmiati. (2013). Efektifitas Pembelajaran Matematika Realistik dengan Setting Kooperatif tipe TAI dan TGT Materi Volume Bangun Ruang pada Kelas $V$ SD Inpres Bakung II. Thesis. Tidak Diterbitkan. Makassar: Pascasarjana Universitas Negeri Makassar.

Hidayat. (2009). Pengertian Efektifitas. (Online).

http://dansite.wordpress.com/2009/03/

28/pengertian-efektifitas/. Diakses pada tanggal 05 Maret 2014.

Idi, Abdullah. (2010). Sosiologi Pendidikan. Jakarta Utara: PT Raja Grapindo Persada.

Iskandar. (2012). Psikologi Pendidikan sebuah Orientasi Baru. Jakarta: Referensi.

Kusnandi. (20110. Pengaruh Penerapan Bimbingan Manajemen Diri Terhadap Tingkat Kemandirian Siswa Dalam Belajar Di SMP Negeri 33 Makassar. Thesis, Tidak Diterbitkan. Makassar: Pascasarjana Universitas Negeri Makassar.

Nurdin. (2007). Model Pembelajaran Matematika yang Menumbuhkan Kemampuan Metakognitif untuk Menguasai Bahan Ajar. Disertasi. Tidak Diterbitkan. Surabaya. PPs UNESA.

Nurhayati, Eti. (2011). Psikologi Pendidika Inovatif. Yogyakarta: Pustaka Pelajar

Nurkancana, Wayan. (1983). Evaluasi Pendidikan. Surabaya: Usaha Nasional

Parondah, Naimah. (2010). Keefektifan Pembelajaran Kooperatif tipe NHT dengan Konsep Pendekatan Problem Possing dalam Pembelajaran Matematika di SMP.Thesis. Tidak Diterbitkan. Makassar: Pasca sarjana Universitas Negeri Makssar.

Ratumanan, Tanwey Gerson. (2003). Evaluasi Hasil Belajar yang Relevan dengan Kurikulum Berbasis Kompetensi. Surabaya: UNESA University Press.

Rusman. (2012). Model-Model Pembelajaran; Mengembangkan Profesionalisme Guru Edisi Kedua. Jakarta: Rajawali Pers.

Sanjaya, Wina. (2009). Strategi Pembelajaran berorientasi Standar proses 
Pendidikan. Jakarta: Kencana Prenada Media Group.

Sardiman. (2010). Interaksi dan Motivasi Belajar Mengajar. Jakarta: PT Grafindo Persada.

Song, Lian and Janette. (2007). A Conceptual Model For Understanding SelfDirected Learning In Online Environments. Jurnal Internasional (Online).www. nclor. Org/jiol. Diakses pada tanggal 25 Oktober 2013.Univercity Of Georgia.

Sriyanti. (2012). Pengembangan Perangkat Pembelajaran Kooperatif TPS pada Materi Pokok Larutan penyangga. Thesis. Tidak Diterbitkan. Makassar. Pascasarjana Universitas Negeri Makassar.

Sukino. (2006). Matematika untuk SMP kelas VIII. Jakarta: Erlangga.

Supiati. (2011). Hubungan antara Pengasuhan Orang Tua, Kedisiplinan dan Kemandirian Belajar Siswa di SMP Negeri 3 Makassar. Thesis. Tidak Diterbitkan. Makassar. Pascasarjana Universitas Negeri Makassar

Tahar, Irzan. (2006). Hubungan Kemandirian Belajar dan Hasil Belajar pada Pendidikan Jarak Jauh. Jurnal nasional (Online). Universitas Terbuka: Jurnal Pendidikan Terbuka dan Jarak jauh.

Thobroni, Mustofa. (2011). Belajar dan Pembelajaran. Jogjakarta: Ar-Ruzz Media.

Trianto. (2009). Mendesain Model Pembelajaran Inovatif Progresif. Jakarta: Kencan Prenada.

Trianto. (2011). Mendesain Model Pembelajaran Inovatif berorientasi konstruktivistik, Konsep, Landasan, dan impelementasinya. Jakarta: prestasi Pustaka Publisher.

Wahyuni, Risda. (2012). Model Pembelajaran Kooperatif tipe NHT. (Online). http://mi1kelayu.blogspot.com/2012/0 6/model-pembelajaran-kooperatif-tipen.html. Diakses pada tanggal 08 Desember 2013.

Yamin, martinis. (2013). Pardigma Baru Pembelajaran. Jakarta: Referensi. 